\title{
The Future Of Nontraditional Occupations For Women: A Comprehensive Review Of The Literature And Implications For Workplace Learning And Performance
}

Kenneth Zula, University of Scranton, USA

\begin{abstract}
The United States entrance into World War II in 1941 has been credited with beginning a large movement of women into the workforce and the commencement of governmental support for women working in nontraditional occupations. However, the beginning of the support for women in the workforce can be traced back to the 1920 federal mandate to create the Women's Bureau within the United States Department of Labor. The United States Department of Labor Women's Bureau is the only federal agency mandated to represent the needs of wage-earning women in the public policy process. The workingwomen tradition has continued into modern day and the number of workingwomen continues to increase steadily, however, the number of women entering nontraditional occupations has declined to 4.9 percent from 7.1 percent in 1983.
\end{abstract}

There has been an effort to increase the number of women in nontraditional occupations in order to increase high skill/high wage employment to provide women with the opportunity for selfsufficiency. Women predominately are employed as clerical workers, childcare providers, sales clerks, and in other low skill/low wage employment, which does not lead to self-sufficiency. Workingwomen largely remain in nonprofessional occupations (73\%), where NTO gains have been minimal.

This study provided the preliminary exploratory of the literature to establish best practice guidelines to encourage women to enter non-traditional occupations (NTO). The major factor identified from literature is career self-efficacy. Career self-efficacy can be increased through: performance accomplishments, vicarious learning, verbal persuasion, and emotional arousal.

The results of this study reveal that women have perceived challenges to nontraditional occupations, which are rather easily overcome but have been a hindrance to their pursuing nontraditional employment. Challenges include sex-role socialization, discrimination and harassment, transportation and childcare issues, the nontraditional workplace may be hazardous which requires special equipment or gear, extreme weather conditions, and the potential job related injuries.

This study has indicated and established a positive correlation for the use of best practice guidelines in career counseling and development in regard to career decision-making. Career development and career counseling for NTO's requires a set of guidelines. The guidelines for NTO's should include best practice within the industry or field. Best practice guidelines ensure a common, consistent approach to successfully achieve the highest and best possible outcome. Formal training and education for NTO's have a prescribed set of best practice guidelines. The best practices guidelines for career counseling and career development programs for women 
entering NTO's include: (1) focusing on performance accomplishments, (2) participating in observational learning, (3) attending to emotional arousal, and (4) receiving verbal persuasion and encouragement.

Keywords: Non-Traditional Occupations (NTO), Women; Workplace Learning and Performance

\section{INTRODUCTION}

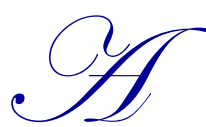

lthough, once considered a background variable, gender is recognized as an important factor influencing career development and career choice. The heightened awareness may be attributed to the fact that women remain underrepresented in many fields, enter low-paying, lower-status occupations, under use their abilities and talents, and are less likely to advance to higher levels in their professions (Sullivan \& Mahalik, 2000). Gender influences on career development and career counseling continue to impede female entry and advancement in high wage/high skill occupations.

Hackett and Betz's (1981) research on women's career development has identified both internal and external barriers associated with women's career development, documenting that the processes of career decision making and maintaining a career are more complex and restricted for women than men (as cited in Sullivan \& Mahalik, 2000, p. 54). Hatckett and Betz's (1981) research has also indicated the need for female specific career development programs based on the identified internal and external barriers and the underestimation of gender on career development.

The purpose of this research was to determine the effects of social learning theory and self-efficacy on female career development and career choice through a comprehensive review of literature. The study examined the historical prospective of career development for women and completed a review of research to investigate if there is a positive correlation between self-efficacy and career development for females.

A positive correlation between self-efficacy and career development, may be an indication for the establishment of best practice guidelines for workplace learning and performance programs. If a positive correlation is established within the literature and research, best practice guidelines can be developed and successfully implemented to assist women with positive career choice. A positive career choice may provide for better wages, benefits, and job satisfaction for females. These better wages, benefits, and higher job satisfaction can assist in creating self-sufficiency for women.

\section{REVIEW OF LITERATURE}

On December 7, 1941, The United States of America entered World War II following the great attack on Pearl Harbor naval base on the island of Oahu in Hawaii. The United States' entry into the world war extracted men from the workforce in the country to fight for freedom in foreign lands, a freedom the citizens of the United States still enjoy today. With the majority of men gone to war, a great void was left in the workforce. The demand for labor and economic survival of families forced women to work in nontraditional employment manufacturing machinery, ammunition, and other war materials. The term Rosie the Riveter was coined after the Fisher-Body General Motors plant in Michigan began training women for riveter positions in the factory making B29 bombers. These women became known as the soldiers without guns. A review of the United States Department of Defense (2013, II 7) documentation reveals, "The Rosie the Riveter movement is credited with helping push the number of working women to 20,000,000 during four years of war, a 57 percent jump from 1940. About 300,000 women were employed in War Department activities in November 1943."

The United States entrance into World War II in 1941 has been credited with beginning a large movement of women into nontraditional occupations and governmental support for women working in nontraditional occupations. However, the beginning of the support for women in the workforce can be traced back to the 1920 federal mandate to create the Women's Bureau within the United States Department of Labor. The United States Department of Labor Women's Bureau is the only federal agency mandated to represent the needs of wage-earning 
women in the public policy process (U.S. Department of Labor [U.S. DOL], 2013c). The workingwomen tradition has continued into modern day and the number of workingwomen continues to increase steadily, however, the number of women entering nontraditional occupations has declined to 4.9 percent from 7.1 percent in 1983 (U.S. DOL, 2013c, II 3).

Table 1: 20 Leading Occupations of Employed Women. Full-Time Wage and Salary Workers 2010 Annual Averages (Employment in thousands)

\begin{tabular}{|c|c|c|c|c|}
\hline Occupation & $\begin{array}{c}\text { inual Averages (E } \\
\text { Total Employed } \\
\text { Women }\end{array}$ & $\begin{array}{l}\text { oyment in thousands) } \\
\text { Total Employed } \\
\text { (Men and Women) }\end{array}$ & $\begin{array}{l}\text { Percent } \\
\text { Women }\end{array}$ & $\begin{array}{l}\text { Women's Median } \\
\text { Weekly Earnings }\end{array}$ \\
\hline $\begin{array}{l}\text { Total, } 16 \text { years and older (all employed } \\
\text { women) }\end{array}$ & 65,638 & 139,064 & $47.2 \%$ & $\$ 669$ \\
\hline Secretaries and administrative assistants & 2,962 & 3,082 & 96.1 & 657 \\
\hline Registered nurses & 2,590 & 2,843 & 91.1 & 1,039 \\
\hline Elementary and middle school teachers & 2,301 & 2,813 & 81.8 & 931 \\
\hline Cashiers & 2,291 & 3,109 & 73.7 & 366 \\
\hline Retail salespersons & 1,705 & 3,286 & 51.9 & 421 \\
\hline $\begin{array}{l}\text { Nursing, psychiatric, and home health } \\
\text { aides }\end{array}$ & 1,700 & 1,928 & 88.2 & 427 \\
\hline Waiters and waitresses & 1,470 & 2,067 & 71.1 & 381 \\
\hline $\begin{array}{l}\text { First-line supervisors/managers of retail } \\
\text { sales workers }\end{array}$ & 1,375 & 3,132 & 43.9 & 578 \\
\hline Customer Service Representatives & 1,263 & 1,896 & 66.6 & 586 \\
\hline Maids and housekeeping cleaners & 1,252 & 1,407 & 89.0 & 376 \\
\hline Receptionists and information clerks & 1,187 & 1,281 & 92.7 & 529 \\
\hline Childcare workers & 1,181 & 1,247 & 94.7 & 398 \\
\hline $\begin{array}{l}\text { Bookkeeping, accounting, and auditing } \\
\text { clerks }\end{array}$ & 1,179 & 1,297 & 90.9 & 628 \\
\hline $\begin{array}{l}\text { First-line supervisors/managers of office } \\
\text { and administrative support }\end{array}$ & 1,035 & 1,507 & 68.7 & 726 \\
\hline Managers, all others & 1,014 & 2,898 & 35.0 & 1,045 \\
\hline Accountants and auditors & 989 & 1,646 & 60.1 & 953 \\
\hline Teacher assistants & 893 & 966 & 92.4 & 485 \\
\hline Personal and home care aids & 838 & 973 & 86.1 & 405 \\
\hline Office clerks, general & 837 & 994 & 84.2 & 597 \\
\hline Cooks & 790 & 1,951 & 40.5 & 381 \\
\hline
\end{tabular}

Note: Source - U.S. Department of Labor, Bureau of Labor Statistics, Annual Averages 2010.

The bureau has been charged with increasing the number of women in nontraditional occupations in order to increase high skill/high wage employment to provide women with the opportunity for self-sufficiency (U.S. DOL, 2013c). Women predominately are employed as clerical workers, childcare providers, sales clerks, and in other low skill/low wage employment, which does not lead to self-sufficiency. Workingwomen largely remain in nonprofessional occupations (73\%), where NTO gains have been minimal (WiderOpportunties4Women (WOW), $2013 \mathrm{~d}, \boldsymbol{9}$ ). The women's bureau has been attempting to reverse this trend for over 83 years.

Table 2: Leading Non-Traditional Occupations (NTO's) of Employed Women 2010 Annual Averages (Employment in thousands)

\begin{tabular}{lccc}
\hline \multicolumn{1}{c}{ Occupation } & $\begin{array}{c}\text { Total Employed } \\
\text { (Both Sexes) }\end{array}$ & $\begin{array}{c}\text { Total Employed } \\
\text { Women }\end{array}$ & $\begin{array}{c}\text { Percent } \\
\text { Female }\end{array}$ \\
\hline Cutting, punching, and press machine setters, operators, and tenders, & 78 & 16.5 & 21.1 \\
metal, and plastic & 1,026 & 214.4 & 20.9 \\
Computer software engineers & 993 & 206.5 & 20.8 \\
Security guards and gaming surveillance officers & 57 & 11.5 & 20.2 \\
Chiropractors & 159 & 31.8 & 20 \\
Industrial engineers & 337 & 64 & 19 \\
Chefs and head cooks & 691 & 129.9 & 18.8 \\
Miscellaneous agricultural workers & 337 & 61 & 18.1 \\
Metal workers and plastic workers, all other & & & \\
\hline
\end{tabular}


Table 2 cont.

\begin{tabular}{|c|c|c|c|}
\hline First-line supervisors/managers of production and operating workers & 702 & 127.1 & 18.1 \\
\hline Farm, ranch, and other agricultural managers & 237 & 42.9 & 18.1 \\
\hline Announcers & 52 & 9.4 & 18 \\
\hline Grounds maintenance workers & 1,195 & 69.3 & 5.8 \\
\hline Baggage porters, bellhops, and concierges & 77 & 13.8 & 17.9 \\
\hline Chemical processing machine setters, operators, and tenders & 58 & 10.3 & 17.7 \\
\hline Metal and plastic & 55 & 9.7 & 17.6 \\
\hline Clergy & 429 & 75.1 & 17.5 \\
\hline Chemical engineers & 63 & 11 & 17.4 \\
\hline Laborers and freight, stock, and material movers, hand & 1,700 & 295.8 & 17.4 \\
\hline Transportation, storage, and distribution managers & 278 & 48.4 & 17.4 \\
\hline Job printers & 50 & 8.6 & 17.3 \\
\hline Network and computer systems administrators & 229 & 37.8 & 16.5 \\
\hline Motor vehicle operators, all other & 54 & 8.5 & 15.8 \\
\hline Crushing, grinding, polishing, mixing, and blending workers & 90 & 14.1 & 15.7 \\
\hline Couriers and messengers & 270 & 41.6 & 15.4 \\
\hline First-line supervisors/managers of police and detectives & 103 & 15.9 & 15.4 \\
\hline Cleaners of vehicles and equipment & 333 & 49.9 & 15 \\
\hline Taxi drivers and chauffeurs & 390 & 56.2 & 14.4 \\
\hline Precision instrument and equipment repairers & 73 & 10.1 & 13.8 \\
\hline Service station attendants & 77 & 10.4 & 13.5 \\
\hline Police and sheriff's patrol officers & 714 & 92.8 & 13 \\
\hline Engineering technicians, except drafters & 374 & 49.4 & 13.2 \\
\hline Engineers, all other & 334 & 43.1 & 12.9 \\
\hline Parts salespersons & 129 & 16.1 & 12.5 \\
\hline Cost estimators & 115 & 13.3 & 11.6 \\
\hline Computer, automated teller, and office machine repairers & 305 & 33.5 & 11 \\
\hline Surveying and mapping technicians & 61 & 6.6 & 10.9 \\
\hline Aerospace engineers & 126 & 13.6 & 10.8 \\
\hline Computer hardware engineers & 70 & 7.2 & 10.3 \\
\hline Broadcast and sound engineering technicians \& radio operators & 102 & 10.1 & 9.9 \\
\hline Civil engineers & 318 & 30.8 & 9.7 \\
\hline Radio and telecommunications equipment installers and repairers & 166 & 15.1 & 9.1 \\
\hline $\begin{array}{l}\text { Grinding, lapping, polishing, and buffing machine tool setters, operators, } \\
\text { and tenders, metal and plastic }\end{array}$ & 54 & 4.9 & 9 \\
\hline Construction and building inspectors & 104 & 9 & 8.7 \\
\hline Material moving workers, all other & 59 & 5.1 & 8.7 \\
\hline Home appliance repairers & 53 & 4.3 & 8.1 \\
\hline Refuse and recyclable material collectors & 80 & 6.3 & 7.9 \\
\hline Painting workers & 139 & 11 & 7.9 \\
\hline Engineering managers & 113 & 8.7 & 7.7 \\
\hline Electrical power-line installers and repairers & 124 & 0.5 & 0.4 \\
\hline Telecommunications line installers and repairers & 163 & 12.2 & 7.5 \\
\hline $\begin{array}{l}\text { First-line supervisors, managers of landscaping, lawn service, and } \\
\text { grounds keeping service }\end{array}$ & 229 & 16.7 & 7.3 \\
\hline Electrical and electronic engineers & 307 & 22.1 & 7.2 \\
\hline Painters, construction and maintenance & 578 & 41.6 & 7.2 \\
\hline $\begin{array}{l}\text { Television, video, and motion picture camera operators and editors \& } \\
\text { radio operators }\end{array}$ & 54 & 3.9 & 7.2 \\
\hline Construction managers & 1,083 & 73.6 & 6.8 \\
\hline Mechanical engineers & 293 & 19.6 & 6.7 \\
\hline Railroad conductors and yardmasters & 58 & 3.8 & 6.5 \\
\hline First-line supervisors/managers of mechanics, installers, and repairers & 381 & 24 & 6.3 \\
\hline Parking lot attendants & 75 & 4.7 & 6.3 \\
\hline Other installation, maintenance, and repair workers & 197 & 12.4 & 6.3 \\
\hline Electronic home entertainment equipment installers and repairers & 52 & 3.1 & 6 \\
\hline Industrial truck and tractor operators & 499 & 30.9 & 6.2 \\
\hline Water and liquid waste treatment plant \& system operators & 77 & 4.5 & 5.9 \\
\hline Welding, soldering, and brazing workers & 479 & 25.9 & 5.4 \\
\hline
\end{tabular}


Table 2 cont.

\begin{tabular}{|c|c|c|c|}
\hline Aircraft pilots and flight engineers & 110 & 5.7 & 5.2 \\
\hline Drivers/sales workers and truck drivers & 3,028 & 139.3 & 4.6 \\
\hline Security and fire alarm systems installers & 60 & 2.6 & 4.4 \\
\hline Sheet metal workers & 108 & 4.3 & 4 \\
\hline $\begin{array}{l}\text { First-line supervisors/mangers of construction trades and extraction } \\
\text { workers }\end{array}$ & 659 & 25.7 & 3.9 \\
\hline Machinists & 408 & 15.9 & 3.9 \\
\hline Computer control programmers and operators & 56 & 2.2 & 3.9 \\
\hline Maintenance and repair worker, general & 347 & 13.2 & 3.8 \\
\hline Firefighters & 301 & 10.8 & 3.6 \\
\hline Industrial and refractory machinery mechanics & 447 & 15.6 & 3.5 \\
\hline Pest control workers & 76 & 2.5 & 3.3 \\
\hline Helpers, construction trades & 60 & 2 & 3.3 \\
\hline Dredge, excavating, and loading machine operators & 51 & 1.6 & 3.2 \\
\hline Mining machine operators & 60 & 1.8 & 3 \\
\hline Maintenance and repair workers, general & 347 & 13.2 & 2.8 \\
\hline Cabinet makers and bench operators & 62 & 1.7 & 2.8 \\
\hline Construction laborers & 1,267 & 34.2 & 2.7 \\
\hline Drywall installers, ceiling tile installers, and tapers & 171 & 4.3 & 2.5 \\
\hline Highway maintenance workers & 110 & 2.7 & 2.5 \\
\hline Locomotive engineers an operators & 57 & 1.5 & 2.6 \\
\hline Aircraft mechanics and service technicians & 136 & 3.1 & 2.3 \\
\hline Small engine mechanics & 57 & 1.1 & 2 \\
\hline Stationery engineers and boiler operators & 91 & 1.5 & 1.7 \\
\hline Operating engineers and other construction equipment operators & 363 & 5.4 & 1.5 \\
\hline Electricians & 691 & 10.4 & 1.5 \\
\hline Pipe layers, plumbers, pipe fitters, and steam fitters & 526 & 7.9 & 1.5 \\
\hline Carpenters & 1,242 & 17.4 & 1.4 \\
\hline Other extraction workers & 55 & 0.8 & 1.4 \\
\hline Automotive body and related repairers & 168 & 2 & 1.2 \\
\hline Heavy vehicle and mobile equipment service technicians and mechanics & 235 & 2.8 & 1.2 \\
\hline Logging workers & 63 & 0.7 & 1.1 \\
\hline Roofers & 214 & 2.1 & 1 \\
\hline Tool and die makers & 68 & 0.6 & 0.9 \\
\hline $\begin{array}{l}\text { Miscellaneous vehicle and mobile equipment mechanics, installers, and } \\
\text { repairers }\end{array}$ & 99 & 0.8 & 0.8 \\
\hline Bus and truck mechanics and diesel engine specialists & 339 & 2.4 & 0.7 \\
\hline Structural iron and rebar workers & 59 & 0.3 & 0.6 \\
\hline Heating, air conditioning, and refrigeration mechanics, and installers & 392 & 2.3 & 0.6 \\
\hline Carpet, floor, and tile installers and finishers & 209 & 1 & 0.5 \\
\hline Electrical power line installers and repairers & 124 & 0.5 & 0.4 \\
\hline Cement masons, concrete finishers, and terrazzo workers & 88 & 0.3 & 0.3 \\
\hline Bricklayers, block masons, and stone masons & 162 & 0.2 & 0.1 \\
\hline
\end{tabular}

Notes: ${ }^{1}$ Nontraditional occupations are those in which women comprise 25 percent or less of total employed. ${ }^{2}$ Data not shown where total employed (both sexes) base is less 50,000. Source: U.S. Department of Labor, Bureau of Labor Statistics, Annual Averages 2010.

The Women's Bureau of the Department of Labor has been charged with representing the interests of workingwomen since 1920. According to the U.S. Department of Labor (2002, p. 45), the number of working females in the United States has steadily increased since 1920 to a projected 48 percent of the labor force by 2010, while the percentage of men will continue to decline to 52 percent by 2010 . The overall percentage of women entering the labor force from 2000 to 2010 is expected to grow significantly. Women are projected to enter the workforce during this 10-year period at an approximate 6 percent higher rate than men (U.S. DOL, 2002). According to the U.S. Department of Labor (2013), women's entry into the workforce peaked in 2012 post the 2008 recession at 47 percent of the workforce. The declining rate of men and increasing rate of women will attribute to a greater need for women to pursue nontraditional occupations as the supply of male workers decline to fill traditional occupations. 
Nontraditional occupations (NTO) are those occupations, which have less than 25 percent females of the total employed workforce (U.S. DOL, 2013b). These occupations comprise some of the highest paying occupations according to the Bureau of Labor Statistics Employment Outlook, 2002-12 such as: chief executives, financial analysts, computer programmers and software engineers, and other professional specialties (Horrigan, 2002). Occupations historically filled by men and those occupations, which continue to be filled predominately by male workforce members, are classified as nontraditional occupations for women.

Nontraditional occupations offer several benefits that enable women and girls to become economically selfsufficient, support their families, and build their assets to obtain a home or pursue a higher education (WOW, 2013a, II 3). Nontraditional occupations are not only some of the highest paying occupations, but are among the fastest growing occupations according to the Bureau of Occupational Statistics Employment Outlook, 2002-12 (Horrigan, 2002). Nontraditional employment for women pays higher wages than traditional employment. It is estimated that 35 percent of positions classified as nontraditional for females will experience growth compared to only 30 percent of those positions classified as traditional.

Benefits of nontraditional occupations for women include higher wages, better benefits, opportunity for advancement, and job satisfaction (WOW, 2013c, II 2). Women in the labor market are concentrated within a few low paying occupations, while men are concentrated in a broader base of occupations that have higher paying wages. Nontraditional occupations pay on average 20 to 30 percent more than the traditional few occupations, which hold the majority of women in the labor market. Any amount of additional income will enable women to pursue self-sufficiency. The majority of nontraditional occupations for women are concentrated in the trade and technical fields, which not only offer higher salary and wage benefits but these jobs tend to be within unionized work environments. Unionized environments not only pay better but also have better fringe benefits. Better-unionized fringe benefits include medical insurance, dental insurance, paid vacation and sick leave, and pension/retirement plans. Some employers also offer transportation assistance and educational subsidies to pay for work-related training or education (WOW, 2013c).

In addition to higher wages and better benefits, many nontraditional occupations offer women and men job advancement opportunities and higher job satisfaction. Most nontraditional employment offers job and/or career ladders. These career ladders lead to higher salary and job advancement because the worker achieves higher skill levels on the job. Often, NTO's offer paid on-the-job training while traditional female occupations do not offer training, which may lead to career advancement (WOW, 2013c). Many traditional female occupations require off the job training or formal education not supplemented by the employer for career advancement. The low wages of traditional employment is usually a hindrance for females to obtain advanced training and/or education thus perpetuating dependence and insufficient wage conditions.

Job advancement opportunities, better wages and benefits are extremely important factors leading to women's pursuit of nontraditional employment; however job satisfaction is another important factor as well (WOW, 2013c). Job satisfaction or on-the-job satisfaction creates higher self-esteem, higher morale among employees, and higher employee output, which ultimately leads to higher profits and overall higher employee/employer satisfaction rates. Women's interests and abilities are diverse. Many women are unhappy with the employment available in traditional occupations, however they may be unaware of the options available to them. "By expanding the number of jobs women enter, women are more likely to find a closer occupational fit with their skills, interests and personalities. In turn, the more a woman enjoys her work, the more likely she is to stick with it and the more likely her family, her community and her employers will benefit from it” (WOW, 2013d, II 3).

Women have perceived challenges to nontraditional work, which are rather easily overcome but have been a hindrance to their pursuing nontraditional employment. Challenges include sex-role socialization, discrimination and harassment, transportation and childcare issues, the nontraditional workplace may be hazardous which requires special safety clothing and equipment, extreme weather conditions, and job related injuries. Beyond work site issues, there are social challenges to be considered: on-the-job isolation related to being the sole female employed and nonsupportive family and friends because of stereotyping and ignorance about non-traditional occupations for women. These challenges need not be a hindrance for females interested in nontraditional employment; there are numerous 
support services, support groups, and social agencies which are willing to help women overcome any of these barriers (WOW, 2013c).

Government intervention to increase the number of women in nontraditional employment has occurred several times since World War I. Masteracci (2003) studied the public policy efficacy for women in NTO's and found "that policy interventions targeting NTO's provide non-college workers with high wage, high skilled career opportunities because NTO's are linked to higher wages, marketable skill training, and opportunities for advancement" (p. 586). To train a woman for a nontraditional occupation is to provide a route out of the low paying traditional occupations that commonly employ females. To provide training and education to women for a NTO leads to self-sufficiency.

Career counseling and career development are important factors for women who enter nontraditional occupations. Career counseling is an assisted process to determine individual occupational interests, strengths, and weaknesses in order to assist in the development of these desires and interests. According to Rothwell and Sredl (2000), career development comprises both individually orientated career planning and organizational - orientated career management. Career planning helps individuals identify future job or occupational opportunities inside and outside their organizations; career management helps organizations identify the number and kind of people needed to meet future work requirements (p. 12).

Educators and workforce development professionals can assist females with nontraditional occupation career choice utilizing a variety of mechanisms. These mechanisms should include: (1) introduce women and girls to high-wage nontraditional occupation career options, (2) train women and girls for nontraditional high-wage employment, (3) place girls in high-wage nontraditional occupations, and (4) support women's and girls' entrance, retention, and advancement in high-wage nontraditional occupations and training programs (WOW, 2013d).

Educators and career counselors need to introduce females to high-wage nontraditional employment which leads to self-sufficiency through the use of appropriate definitions of NTO's, clear explanations of the benefits and challenges of a NTO, discuss the myths and facts of NTO's and provide statistics and research to provide concrete data to support women in NTO's. Educators and workforce development professionals must also provide women and girls with current occupational outlook projections and help with the interpretation of the data thus enabling female students and workers to make informed decisions (WOW, 2013d).

Workforce development professionals need to be trained in the proper administration and scoring of alternative career assessment tools. Most career assessment tools are gender biased and do not accurately measure female likes, dislikes, and career interests. However, there are non-gender biased career assessment instruments such as The Nontraditional Employment for Women Career Assessment Survey, Nontraditional Self-Assessment Survey, and the Nontraditional: Is That For Me STEP-UP Assessment from The Northern New England Tradeswomen Association. These three assessments are non-gender biased interest assessments for women. These instruments are used in addition to common vocational aptitude and interest assessments (WOW, 2013g).

Workforce development professionals should provide training to females for nontraditional employment opportunities. This does not necessarily indicate that the training is provided in-house or on school grounds, however, if a female student indicates an interest in a nontraditional occupation, an educator or workforce development professional should be able to provide instructions or directions on how to locate an apprenticeship and/or training program; they should maintain or know how to gain access to a database of nontraditional occupation training programs, and provide an occupational overview so females can plan an appropriate training path for their career (WOW, 2013d).

Another important realm for educators and workplace development professionals is to place females in high-wage nontraditional occupations. The placement of women into nontraditional occupations requires providing occupational overviews, utilizing assessment tools, and assisting females to find nontraditional occupations. Females must also be informed on the barriers, which face them in nontraditional occupations and where to locate resources to combat these barriers. 
Resources must be provided to assist females with nontraditional interests with role models, support services, and other resources available to them. The most important factor to the success of women in nontraditional occupations is providing mentors and role models (WOW, 2013d). This type of relationship provides on-the-job support, mentorship, and performance accomplishment reinforcement to female workers. Without this type of relationship success may be limited! This key element may ensure successful entrance, retention, and advancement for women in high-wage nontraditional occupations and education and training programs.

Sullivan and Mahalik (2000) conducted a research study to investigate career choices with female students and how to overcome the barriers (career attitudes, self-esteem, female attitudes towards women, sex-types socialization, sex-role self concept) which women are exposed, thus leading to less career efficacy. Women are less exposed to positive career and vocational choices, thus leading to less self-sufficient career decisions. Sullivan and Mahalik believed that if they removed the barriers to career decision-making that women would make positive career choices resulting in self-efficacy.

The research study utilized a career group treatment for a six sessions over a six-week period of time to provide necessary skill intervention to modify self-efficacy in women. Self-efficacy is considered a cognitive structure created by cumulative learning experiences that leads to the belief or expectation that one can successfully perform a specific task or activity (Sullivan \& Mahalik, 2000). Self-efficacy can be modified with four levels of experiential information - performance accomplishments, vicarious learning, emotional arousal, and verbal persuasion.

The research study investigated the effects of the four levels of self-efficacy on the psychological barriers to women regarding choice, performance, and persistence in career decision-making (Sullivan \& Mahalik, 2000). The researchers addressed the psychological barriers for women specifically for career decisions. The removal or treatment of the barriers should increase career development for women.

The purpose of the Sullivan and Mahalik (2000) study was "to investigate whether a career group intervention that incorporates the four influences on career-related self efficacy and addresses feminine socialization is effective in increasing career decision making for women" (p. 55). Also, the research focused on the affects of career groups on self-efficacy and vocational exploration and commitment. "The hypothesis of the study was that career decision-making self-efficacy and vocational exploration and commitment would increase for women who participate in-group intervention designed to affect career-related self-efficacy compared with women in a no treatment control group" (Sullivan \& Mahalik, 2000, p. 55).

In the Sullivan and Mahalik (2000) study there were sixty-one female participants from three universities (31 in the treatment group, and 30 in the control group). Participants were administered three screening measures The Career Decision Scale, The Career Decision-Making Self-Efficacy Scale, and the Commitment to Career Choices Scale. Female participants required an aggregate score in the $85^{\text {th }}$ percentile to be selected for the research study. The $85^{\text {th }}$ percentile indicated moderate to high career indecision.

Sullivan and Mahalik (2000) structured "the intervention into group sessions, which consisted of didactic and experiential learning exercises and group counseling. The didactic and experiential learning sessions were designed to emphasize career choice as a process and to increase career decision-making self-efficacy" (p. 57). The group counseling sessions incorporated Bandura's four sources for modifying self-efficacy (as cited in Sullivan \& Mahalik, 2000) in career decision-making. Participants were to learn about career decision-making as a process, have group members share experiences how parental models influenced their career development, and interview a successful female role model about her career decision-making process (Sullivan \& Mahalik, 2000).

The results indicated that women in a career counseling group who incorporated Bandura's four sources of modifying self-efficacy (as cited in Sullivan \& Mahilik, 2000) increased career decision-making self-efficacy and vocational exploration and commitment. The results support strategies for increasing career development for females through the utilization of performance accomplishments, vicarious learning, emotional arousal, and verbal persuasion (Sullivan \& Mahalik, 2000). The researchers claim, "treatments such as the one in this study that increase career decision-making self-efficacy should positively affect career indecision, self-esteem, and attitudes related to women, gender-type socialization, and gender role self-concept" (Sullivan \& Mahalik, 2000, p. 60). 


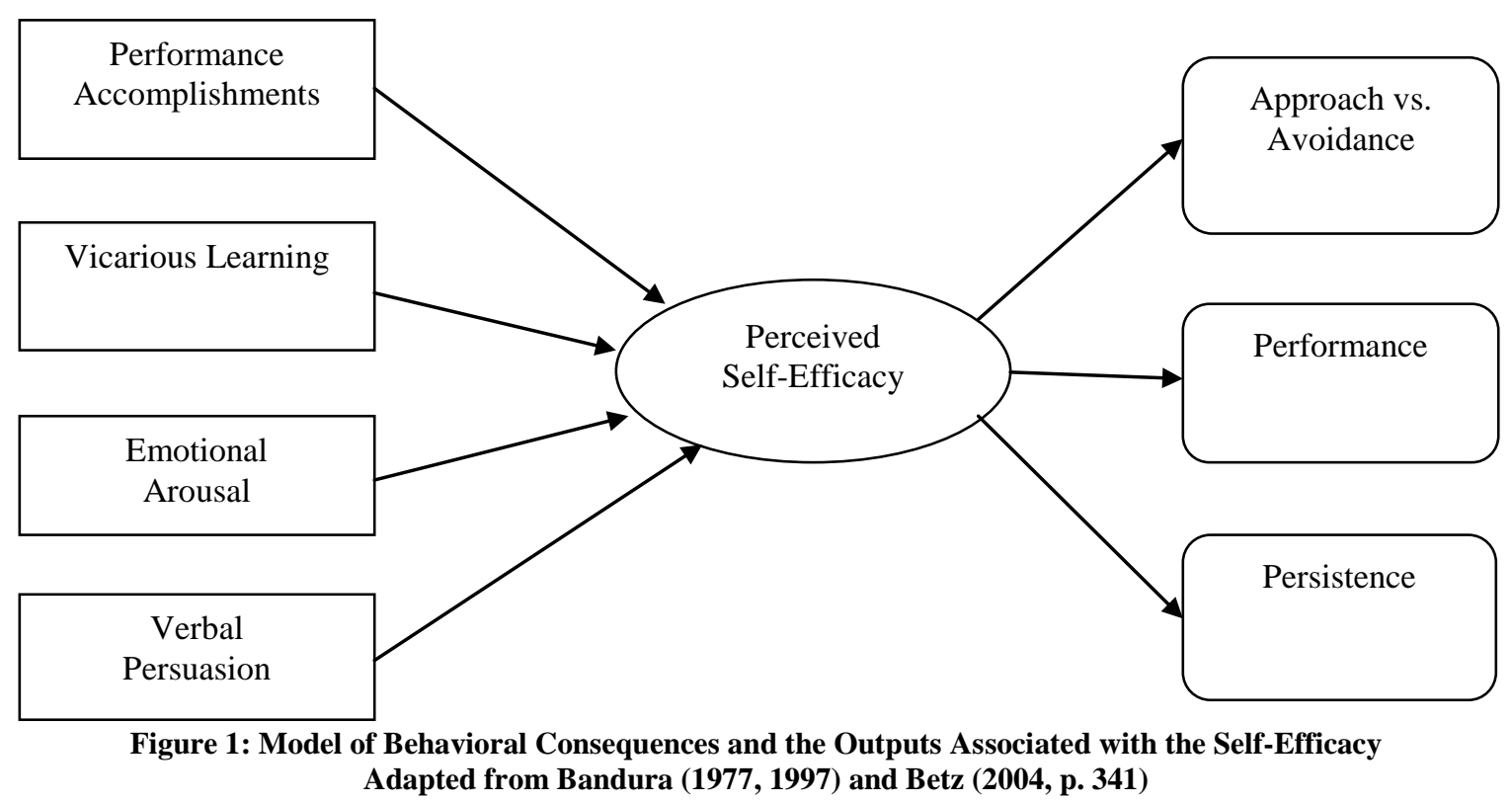

The results of the Sullivan and Mahalik research study indicate and establish a positive correlation for the use of best practice guidelines in career counseling and development in regard to career decision-making. Career development and career counseling for NTO's requires a set of guidelines. The guidelines for NTO's should include best practice within the industry or field. Best practice guidelines ensure a common, consistent approach to successfully achieve the highest and best possible outcome. Formal training and education for NTO's have a prescribed set of best practice guidelines. The best practices guidelines for career counseling and career development programs for women entering NTO's include: (1) focusing on performance accomplishments, (2) participating in observational learning, (3) attending to emotional arousal, and (4) receiving verbal persuasion and encouragement (Mastracci, 2003, p. 588).

Performance accomplishments are two-fold. For career counseling and career development to be successful, students must be exposed to hands-on skill training in addition to didactic instruction. Students must learn the on-the-job skills in order for the training program to be a success. Women may need or require lessons on tool identification, blue print reading, tool familiarity, strength and fitness training, and workplace vocabulary and protocol (Mastracci, 2003). Women are also encouraged to share their successes and failures with other group members. For example, participants in Sullivan and Mahalik's (2000) experimental groups shared stories of past accomplishments with peer-group members and conducted other positive self-assessment and goal setting exercises.

Counseling and development programs must prepare women beyond the classroom through vicarious or observational learning. Observational learning requires women be assigned a role model, mentor or simply another women in a NTO to shadow on-the-job. This type of experience provides women with the opportunity to be exposed to other women in a NTO and to provide a positive mentoring relationship. An observational learning component in a training program is the key to best practice to ensure a positive outcome. "In addition, many programs incorporate long-term links to businesses and industry to maintain mentoring relationships with women in occupations across firms and fields" (Mastracci, 2003, p. 590).

Women pursuing careers in NTO's must be prepared to develop emotional controls. Skill developments for emotional control include: stress management, anxiety management, conflict resolution techniques, relaxation techniques, and methods to deal with discrimination and harassment (Mastracci, 2003). Anxiety management must also address math anxiety. In the past, math anxiety has been a common factor detracting women from nontraditional career training and education. Another area to be considered is negative self-talk and self-defeating behavior. This behavior can be addressed through specific courses and performance accomplishments. Stress management can be curbed with childcare services, flexible scheduling, and training stipends. These benefits may assist in reducing off-the-job stress, which frequently is carried on to the job. 
Encouragement and persuasion must be addressed at the commencement of career planning and development and throughout the process. In other words, women need to be recruited into the trades and once recruited; they need to be persuaded to stay in the trade industry. NTO training programs need to provide positive feedback and encouragement because women may rarely receive it once on the job. Also, performance accomplishments need to be addressed on a consistent basis to encourage and persuade female employees in nontraditional employment.

\section{IMPLICATIONS FOR WORKPLACE LEARNING AND PERFORMANCE (WLP) PROFESSIONALS}

Educators, workforce development, workplace learning and performance (WLP), and human resource management professionals can assist females to train for nontraditional occupations and to succeed in NTO's as well as assist in retention of females in nontraditional occupations. Career counselors and, in particular, WLP professionals can introduce women and girls to high-wage nontraditional occupation career options. Since high wage occupations lead to self-sufficiency, women need to be trained and retained in such occupations. Women may require encouragement to become involved in such training programs. Women involved in the construction industry numbered 784,000; however, only $12.4 \%$ were involved in production and crafting (WOW, 2013f). Most women in the construction industry fill clerical, technical, and other support positions. WLP professionals can encourage women in low-wage support positions in the construction industry to switch sides to the high-wage production and crafter positions through training and other development activities.

WLP professionals can help women overcome some of the largest barriers in the field by utilizing best practice regarding lack of knowledge about the trades, and by providing mentors and role models. Gayle NelsonBlomquist (2003) said, "The biggest problems are lack of knowledge about the fields, women underestimating their own skills and the absence of role models. Even if you offer vocational training to girls, if they don't see anyone who looks like them doing it, they are not likely to picture themselves doing it either" (p. K.01).

To ensure success, WLP professionals can conduct job and life skill classes which help participants work on personal issues such as self-esteem, assertiveness, success management, and developing networks, as well as how to maintain a nontraditional job and apprenticeship (Petaia, 1997). This type of skill training can help to ensure success by providing women with improved emotional skills, mentoring relationships, and personal career planning. These trainings, when tailored to women, assist in developing talent needed to fill positions, which are held by a declining male labor population.

WLP professionals must complete frequent needs assessments with females in nontraditional occupations. These needs assessments will provide the data about missing or incomplete skill sets necessary to succeed in a nontraditional occupation. Based on the Bennett, Davidson, \& Galeand (1999) research study of women in construction trades, there is an additional need for training regarding the ability to meet deadlines, ability to manage budgets, ability to maintain quality standards, ability to take decisions and run with them, planning skills, and technological/computer skills (p. 283). The needs assessment must be used to complete a gap analysis of workforce skills. WLP professionals need to conduct needs assessments to determine the skill gaps of employees and in particular, the skill gaps of nontraditional female employees. WLP professionals will need to provide training regarding skill gaps in order to ensure the success of the employee and the organization.

\section{CONCLUSION}

Many occupations essential to the economy do not require a 4-year college degree, including many service sector jobs and skilled trades. Non-college women tend to hold lower-paying jobs with fewer opportunities for advancement, compared with college men. Many employment and training programs for women focused on increasing their numbers in jobs where men dominate, which tend to be higher paying and provide more opportunities for advancement (Mastracci, 2003).

Career counselors, educators, and WLP professionals can provide valuable guidance to females to become self-sufficient in nontraditional occupations by utilizing established best practice guidelines and principles. Best practice principles can successfully assist women with poor career decision-making skills, poor career development, and poor self-esteem. 
In addition, these best practice principles can guide WLP professionals in the development of workplace learning to continue to encourage and support women. For far too long, the workforce has been gender biased and unsupportive of female career decision-making especially for nontraditional occupations. Educators, counselors, and WLP professionals must be aware of gender biases and develop education, counseling, and training programs to continue to assist women to become self-sufficient.

\section{AUTHOR INFORMATION}

Ken Zula, Ph.D, SPHR is an Assistant Professor of Health Administration and Human Resources in the Panuska College of Professional Studies at the University of Scranton. Dr. Zula has worked in the field of health care administration, non-profit management, and human resources for over 12 years. He is a certified Senior Professional in Human Resources (SPHR). He holds a Masters degree in Organizational Management from Misericordia University and a Doctor of Philosophy in Human Resource Development (HRD) from The Pennsylvania State University. Dr. Zula's research interest and focus is on human capital planning and strategic human resource management. In particular, his research has focused on the linkages between talent and organizational strategic direction setting. His research articles have been published in several journals including the Journal of Leadership Studies, Human Resource Development Quarterly (HRDQ), Human Resource Development Review (HRDR), and the Journal of American Business Education. In addition, he has presented his research at numerous national and international conferences including the International Conference on Business and Economics Research (IBER) in Barcelona, Spain, and Dublin, Ireland. Dr. Zula is a member of the Society for Human Resource Management (SHRM), the Academy of Management (AOM), and the Academy of Human Resource Development (AHRD). E-mail: Kenneth.zula@ scranton.edu

\section{REFERENCES}

1. Advice for Twentysomethings (2003, April 20). Why are all the Workmen...Men? The Washington Post. p.K.01.

2. Bandura, A. (1977). Self-efficacy: Toward a unifying theory of behavioral change. Psychology Review, 84, 191-215.

3. Bandura, A. (1997). Self-efficacy: The exercise of control. New York: W.H. Freeman.

4. Betz, N. E. (2004). Contributions of self-efficacy theory to career counseling: A personal perspective. The Career Development Quarterly, 52, 340-353.

5. Bennett, J. F., Davidson, M. J., \& Galeand, A. W. (1999). Women in construction: A comparative investigation into the expectations and experiences of female and male construction undergraduates and employees. Women in Management, 14(7).

6. Daly, A. C., \& Herman, A. M. (1999, November 24). USDOL awards $\$ 78,579$ to Mi Casa to promote women in non-traditional occupations. La Voz, XXV(47), 20.

7. Horrigan, M. W. (2004). Employment outlook, 2002-12: Employment projections to 2012: Concepts and context. Monthly Labor Review, 3-22.

8. Mastracci, S. H. (2003). Employment and training alternatives for non-college women: Do redistributive policies really redistribute? Policy Studies Journal, 31(4).

9. Northern New England Tradeswomen. (n.d.). Non-traditional - Is it for me? Step-up for women curriculum. $\left(2^{\text {nd }}\right.$ ed.).

10. Petaia, N. (1997, June 6). Making the move to non-traditional employment: Vocational school helps lowincome women make the move. Northwest Asian Weekly, 16(24), 11.

11. Rothwell, W. J., \& Sredl, H. J. (2000). The ASTD reference guide to workplace learning and performance: Present and future roles and competencies $\left(3^{\text {rd }}\right.$ Ed.). Amherst, MA: HRD Press.

12. Sullivan, K. R., \& Mahalik, J. R. (2000). Increasing career self-efficacy for women: Evaluating a group intervention. Journal of Counseling and Development, 7, 54-61.

13. United States Department of the Defense (n.d.). Rosie the Riveter more than a poster girl. US Army Ordnance Corps. Retrieved March 31, 2013 from http://www.goordnance.army.mil/history/rosie.html

14. United States Department of Labor. Bureau of Labor Statistics. (2013). Labor Force. Occupational Outlook Quarterly, Winter 2013-14. 
15. United States Department of Labor. Women's Bureau. (2013a). 20 leading occupations for employed women. Retrieved February 20, 2013 from http://www.dol.gov/wb/factsheets/20lead2010.htm

16. United States Department of Labor. Women's Bureau. (2013b). Nontraditional occupations for women in 2010. Retrieved June 20, 2013 from http://www.dol.gov/wb/nto/2010.htm

17. United States Department of Labor. Women's Bureau. (2013c). Women's Bureau-An overview 19202003. Retrieved February 20, 2013 from: http://www.dol.gov/wb/nto/2002.htm

18. Wider Opportunities for Women (n.d.). Nontraditional Employment for Women: Career Assessment Survey.

19. Work4Women: A project of WOW. (2013a). Alternative assessment approaches. About NTO's. Retrieved March 12, 2013 from http://wowonline.org

20. Work4Women: A project of WOW. (2013b). Alternative assessment tools for nontraditional employment. Assessment Tools. Retrieved March 12, 2013 from http://wowonline.org

21. Work4Women: A project of WOW. (2013c). Benefits and challenges of working in NTO's. Benefits and Challenges. Retrieved March 12, 2013 from http://wowonline.org

22. Work4Women: A project of WOW. (2013d). Educators and workforce development professionals. Educators and Workforce Development Professionals. Retrieved March 12, 2004 from http://wowonline.org

23. Work4Women: A project of WOW. (2013e).Evaluating assessment tools for biases. Assessment Tools. Retrieved March 12, 2013 from http://wowonline.org

24. Work4Women: A project of WOW. (2013f). Statistical research about women in high-wage nontraditional employment. About NTO's. Retrieved March 12, 2013 from http://wowonline.org

25. Work4Women: A project of WOW. (2013g). Types of assessment tools. Assessment Tools. Retrieved March 12, 2013 from http://wowonline.org 